\title{
The Missed Appointment: A Resident's Journal through Activity to Introspection
}

\author{
Marcia J. Kaplan, MD \\ University of Cincinnati, Cincinnati Ohio
}

Follow this and additional works at: https://jdc.jefferson.edu/jeffjpsychiatry

Part of the Psychiatry Commons

Let us know how access to this document benefits you

\author{
Recommended Citation \\ Kaplan, MD, Marcia J. (1988) "The Missed Appointment: A Resident's Journal through Activity to \\ Introspection," Jefferson Journal of Psychiatry. Vol. 6 : Iss. 2 , Article 6. \\ DOI: https://doi.org/10.29046/JJP.006.2.004 \\ Available at: https://jdc.jefferson.edu/jeffjpsychiatry/vol6/iss2/6
}

This Article is brought to you for free and open access by the Jefferson Digital Commons. The Jefferson Digital Commons is a service of Thomas Jefferson University's Center for Teaching and Learning (CTL). The Commons is a showcase for Jefferson books and journals, peer-reviewed scholarly publications, unique historical collections from the University archives, and teaching tools. The Jefferson Digital Commons allows researchers and interested readers anywhere in the world to learn about and keep up to date with Jefferson scholarship. This article has been accepted for inclusion in Jefferson Journal of Psychiatry by an authorized administrator of the Jefferson Digital Commons. For more information, please contact: JeffersonDigitalCommons@jefferson.edu. 


\title{
The Missed Appointment: A Resident's Journey Through Activity to Introspection
}

\author{
Marcia J. Kaplan, M.D.
}

There was one experience during my medical school psychiatry rotation that I could not forget. In a classroom on the cardiology ward, I listened, transfixed like a child at a magic show, as a psychiatrist interviewed a man who was recovering from a heart attack. Initially the man denied any stresses in his life that might have affected his health, but as he went on, a different story unfolded. He spoke of his recent retirement, his wife's dissatisfactions and hostility, his disappointment with his children, his growing sense of failure and futility, and the recurring tightness in his chest that he had tried to ignore. His doctors colluded in his denial, for they were too busy with his EKGs and cardiac enzymes to wonder about his emotional well-being. I could see the despair, but also the hope in his face as he talked with the psychiatrist. At the end of the interview the patient was in tears, and though I hid them from my colleagues, so was I. Powerful and mysterious stuff, this business of feelings, much more complicated than anything I had yet encountered in my medical training, but also much more threatening. It seemed that talking to patients about their feelings would bring into question my own feelings, a Pandora's box I wasn't ready to open. A seed had been planted, but it was not to be tended to for some time to come.

During my residency in neurology I ventured as close as I dared to understanding my patients' suffering, with the ready refuge of clinical objectivity. I recognized the psychic aspect of each illness, often thinking of the man with the heart attack and the psychiatrist who had helped him discover his feelings. I found it difficult to focus on the physical illnesses while ignoring the psychological ones. The seed had taken root; I was ready to become a psychiatrist.

I came with great enthusiasm and a sense of relief to this new endeavor. I was ready to help patients discover their feelings and realize their full potential for health and happiness. I recognized the naivete of this notion as soon as I began working with inpatients, many of whom were severely ill and seemed to defy my attempts to help. I reassured myself that outpatient psychotherapy would be more satisfying, and it was with eager anticipation that I waited in my office for my first patient to arrive. I did not expect to spend the hour alone watching the minutes tick by. I felt incompetent, and angry at being exposed by the patient who hadn't come. It was easier having ten patients waiting than one who doesn't come.

Patients come or don't come to appointments for many reasons, and one of 
the tasks of the psychotherapist is to understand these reasons. The patient who comes regularly and fills the time with material makes the task straightforward. Even the "difficult patients," the dependent clingers, entitled demanders, manipulative help-rejecters and self-destructive deniers described by Groves (1) are in a sense gratifying to work with, in that they provide specific challenges for the therapist, by which to measure one's skills. These patients are described in detail in standard texts for psychiatric residents. The patients who don't come present a much harder problem, and one that is given surprisingly little mention in these same texts. They may be telling me something about themselves through their absence but I suspect they are also telling me something about me, and in a way that makes understanding more elusive. My usual reference books address psychotherapeutic technique and patients' psychopathology but not residents' responses to this specific situation.

I discuss the problem with supervisors. Their equanimity tells me that the intensity of my response is a function of my inexperience or my own psychopathology. I go back to my reading, and find confirmation in Langs. Though he notes that absence reflects characterological problems in the patient, he writes, "Once the patient is absent, countertransference anxieties, anger, and seductive needs are mobilized in some therapists" (2). What kind of therapists? It seemed clear that in coming to understand the patient it is necessary to learn something about oneself. As physicians we are trained to make diagnoses, to advise and carry out treatments, to cure the diseases our patients present us. We are highly praised when we succeed, but seemingly fail if we are frustrated in these goals. Kohut wrote, "We are used to a continuous draining of tension through action, and are willing to accept thought only as an intermediary to activity, as a delayed action or trial action or planning. Introspection seems to oppose the direction of the current by which we achieve tension relief and may thus add the general dread of passivity and tension increase to the more specific fears that are created when the uncovering of repressed content is in the offing" (3). As psychiatrists we must learn to tolerate passivity and realize that the absence of action may be more helpful for some patients than doing something. For the physician who has been taught to be active, inactivity may be quite uncomfortable. Psychiatric residents may feel especially insecure as they begin their outpatient work. Patients' resistances may make them doubtful of their own abilities, as when a patient doesn't come.

Absences may be an important clue to some problem in the therapeutic relationship. The alliance may not be as strong as one believed, or the maintenance of the framework may have been lax. The therapist may have been sleepy, bored or annoyed during a session. The therapist's comments or lack thereof may signal anger, dislike or contempt. While the resident's inexperience accounts for uncertainty or poor understanding at times, countertransference feelings may play a large part. Feelings can help us understand the person in our office, but only if uncoupled from action. It seems unfair at times that the patient is free to be himself while we must carefully restrict and edit our responses. It 
may help to reflect on one's own therapy and the profound effect of that imbalance between doctor and patient. Once the psychiatrist has discovered his or her own capacity for understanding, it is easier to foster this capacity in patients.

Though I have been largely concerned with my effect on and reaction to patients' absence, I have learned that behavior may be much more intrapsychically than interpersonally derived. In referring to absence in analytic practice, Greenson writes, “Obviously the patient's coming late, missing hours, and forgetting to pay are indications of a reluctance to come or to pay for the analytic hour. Again this can be concious and therefore relatively easily accessible or it may be unconcious in the sense that the patient can rationalize the occurrence. In the latter event it cannot be analyzed until there is enough supporting evidence to confront the patient with the likelihood that he is actively but unconciously doing something to avoid the issue. Only if this point is reached can one approach the underlying source of the resistance" (4). As Greenson suggests, the underlying resistance must be addressed eventually if the therapy is to proceed. While learning to recognize the countertransference aspects of relationships with patients one must not overlook the obvious fact that the patient is communicating something through absence. Both aspects must be considered and held in balance. Some clinical examples will serve to illustrate.

Case 1: A middle-aged woman comes to my office with a dramatic story of a mother who abandoned her, a father who abused her, a grandmother who refused to protect her, a husband who hurt her and children who disappoint her. She has worked diligently to create a more stable environment for her own family and could not understand why her alcoholic husband was unwilling to cooperate and allow this wish to come true. While I did not miss the histrionic style of her communication, her genuine despair evoked in me a wish to help. I admired her forthrightness and accuracy in identifying the problems we should address, as well as her capacity to maintain her ideals in her chaotic surroundings. I was surprised when she missed her second, and many subsequent appointments until I realized that I am seeing how she defends herself in her unreliable world. She anticipates the loss of my support and by not coming prepares for the loss, maintains distance from me and punishes herself for any comfort she might have taken in telling her story. Furthermore, she fears the pain of looking closely at herself as much as she wishes to be happier. She uses me in the only way that she can. My wish to rescue her and my frustration with her absences is tempered by my understanding of her predicament. When I give up my stance as the exasperated would-be rescuer and wonder with her about the meaning of her missed sessions she is able to relax her defenses and look at herself more honestly. Our work takes on a richer meaning for both of us.

Case 2: A man with obsessive and narcissistic traits comes to talk about his repeated failures in developing a satisfying career. His wife reproaches him for not providing financial security for the family and his children suffer from the 
tension between their parents. He is openly skeptical about whether therapy might help, but comes regularly and develops a strong alliance with me. His vigorous disavowal of any feelings about me confirms the strong wish for love and approval I hear in the material, as do my own counter-transference feelings of annoyance with the implicit demands he makes. Therapy progresses well and we both note positive changes: he has gotten a promising job, his wife is pleased, his children are happier at home. I am bewildered by his abrupt cancellation of one session but fear that this heralds my fall from grace. He now wonders whether he should continue; after all, therapy is expensive and time-consuming and is of no clear benefit to him. I try to focus on his experience while reeling with my own sense of rejection and incompetence. He is telling me how little I mean to him and how useless our work has been. I quietly agree that therapy is hard work and the benefits are sometimes elusive, that one must be motivated to go on and that he needn't continue if he has no further interest in our work. When my supervisor wonders why I did not explore with him his reasons for wishing to leave I realize how vengeful I felt. I am aware of the degree of estrangement and sense of undervaluation that mark his relationships with others, and imagine that feeling close to me is risky. His move to leave is powered by his fear that I really do not care for him, and by his wish that I show him that I do. When I suggest this, he admits his wish for reassurance that I value him and will not abandon him. He knows that residents move on at intervals and that I might soon be announcing my departure. After I confirm my availability and understanding of his wish to be cared for, our work continues at a deeper level.

Case 3: A bright young woman in graduate school has had a psychotic episode from which she has emerged, though with much damage to her self-esteem. While she has steadily regained self-assurance I know how devastating a relapse could be, and how important it is that I offer her support without overpowering her. I am touched by her expression of gratitude and trust, and feel proud for not being overprotective. As she improves her attendance becomes erratic; I feel like a devoted, loving parent discarded by a rebellious teenager. I also know that I represent a terrifying experience that she wishes to leave behind. She corroborates my suspicion, thanking me for my help but wishing to discontinue regular appointments. I feel this is a choice I must allow her to make, and that much of my reluctance to do so is born of the pain of being devalued and left. By accepting her terms and leaving the door open I allow our work to go on. She comes infrequently and calls me if problems arise between sessions. We make mutual decisions about the use of medication based on her ability to be honest with me. Her ongoing recovery and growth are certainly facilitated by my acceptance of her.

Case 4: A schizotypal man whose fantasy life eclipses anything the real world might offer him comes regularly and expresses satisfaction with our therapy. He has seen many psychiatrists before me, in the unavoidable incessant 
march of residents through the clinic. I worry about the transition's effect on him, but he assures me that it is no problem. We continue the work begun long ago. He has made slow but considerable progress, and feels our relationship is important to him. His occasional absences concern me until I learn that it is when he is feeling well that he misses sessions, with some pride in his ability to evoke my image in fantasy should he need some help. With this understanding it is easier to let him set the pace.

I have worked with patients whose emotional suffering is hard to distinguish from the losses and deprivations they have suffered. Poor, incapacitated, dispossessed, they are confused by the idea of time spent with a doctor who wants only to understand their experience. It is an unaccustomed luxury to focus on one's own feelings, and one that may feel uncomfortable or futile to some. While I understand that it may be impossible to come to sessions when there is no one to watch the children or no money for busfare, I can't do therapy without the patient in the room. I feel guilty for not being able to offer more, and for wishing that the patient would drop out rather than miss so many sessions. The framework can be flexible but it cannot bend so far that we lose the process. When I learn to accept this limitation I can listen to the patient without feeling responsible for what is beyond my control.

What I have been engaged in is the transition from activity to introspection, one of the greater challenges thus far in my education as a psychiatrist. The reward is of a different nature than that I'm accustomed to, but brings a different and more meaningful satisfaction. This search was begun initially as an inquiry into the role of patients' psychopathology and therapists' technical errors in the phenomenon of missed appointments, and led to a consideration of the emotional determinants of my reaction. Once I understand my own anxieties I can look further in the search. It is far from concluded, but will hopefully span all the years I see patients. One of the most valuable skills of the psychotherapist is the ability to balance the understanding of the patient with that of oneself, and to use that understanding to the benefit of each. It requires a clearer view of oneself than we ordinarily seek. It requires the knowledge that what we hear and see is only the most superficial part of human experience, a clue to what lies beneath. It requires learning to act without action, but through introspection. This is a task that runs counter to my reflex responses and previous training and experience, which value activity and intervention and concrete evidence of success. I will always remember the man with the heart attack whose treatment may have been a success from his cardiologist's point of view but whose condition may have been little improved in his own mind. I like to think that his chance meeting with a psychiatrist contributed to his recovery, if only by showing him that his emotional pain was as real as his chest pain, and that his experience was worthy of being understood. I like to think that I am on my way to achieving that balance between my own feelings and those of my patients, though I may be fully aware of it only now and then. It's a painfully slow, and at times frustrating process, but always worth the struggle. 


\section{REFERENCES}

1. Groves J: Taking care of the hateful patient. N Engl J Med 298:883-887, 1978

2. Langs R: The technique of psychoanalytic psychotherapy; Vol I. New York, J Aronson 140, 1973

3. Kohut H: Introspection, empathy, and psychoanalysis: an examination of the relationship between mode of observation and theory, in Ornstein P, ed. Search for the self. New York, International Universities Press, 209, 1978

4. Greenson R: The technique and practice of psychoanalysis. New York, International Universities Press, 67, 1967 